\title{
Comparison of snow accumulation events on two High-Arctic glaciers to model-derived and observed precipitation
}

\author{
Ankit Pramanik ${ }^{1,2,3}$, Jack Kohler ${ }^{1}$, Thomas V. Schuler ${ }^{2,4}$, Ward van Pelt ${ }^{5}$ \& Lana Cohen ${ }^{1}$ \\ ${ }^{1}$ Norwegian Polar Institute, Tromsø, Norway; \\ ${ }^{2}$ Department of Geosciences, University of Oslo, Oslo, Norway; \\ ${ }^{3}$ National Centre for Polar and Ocean Research, Goa, India; \\ ${ }^{4}$ Arctic Geophysics, University Centre in Svalbard, Longyearbyen, Svalbard, Norway; \\ ${ }^{5}$ Department of Earth Sciences, Uppsala University, Uppsala, Sweden
}

\begin{abstract}
We evaluate how precipitation forcing data used in glacier mass balance models characterize snow accumulation events on synoptic timescales for two glaciers in north-western Svalbard (Kongsvegen and Holtedahlfonna). Using sonic ranger (snow depth) and wind speed data from automatic weather stations located on the glaciers, we distinguish accumulation events occurring under either calm or windy conditions. We show clear differences in the timing and magnitude of snow accumulation events between the two neighbouring glaciers, illustrating the spatial heterogeneity of snow accumulation in this region. The accumulation measurements show that at equivalent elevations, Kongsvegen receives more snowfall than neighbouring Holtedahlfonna, and that Kongsvegen is more affected by wind-driven snow redistribution than Holtedahlfonna. This is consistent with the synoptically-driven precipitation patterns in the region. Accumulation events are then compared to precipitation data from the nearest meteorological station in Ny-Ålesund (ca. $30 \mathrm{~km}$ distant) and to a downscaled snowfall data product based on the ERA-Interim reanalysis (nearest gridpoint ca. $300 \mathrm{~m}$ distant). Evaluation of the synchrony of observed events at the glacier sites and the precipitation products shows that the ERA-Interim precipitation data reproduce more snowfall events than the Ny-Ålesund station data, suggesting that the precipitation fields from distributed reanalysis data provide a more reasonable representation of accumulation on the study glaciers, even over short timescales.
\end{abstract}

\author{
Keywords \\ Sonic ranger; accumulation; precipitation; \\ mass balance; calm snowfall; high wind \\ accumulation
}

\section{Correspondence}

Ankit Pramanik, National Centre for Polar and Ocean Research, Hedland Sada, Vasco da Gama, Goa, 403804, India. E-mail: ankit.pramanik@outlook.com
Abbreviations
AWS: automatic weather station HDF: Holtedahlfonna glacier KNG: Kongsvegen glacier m.w.e.: metre water equivalent RMSE: root mean square error SC: calm snowfall events SW: high-wind accumulation events T12 = 12-hour average of temperature

\section{Introduction}

The main source of glacier mass gain is precipitation, and accurate modelling of mass balance is highly sensitive to the precipitation forcing. Snow plays a crucial role for the albedo of a glacier and, therefore, indirectly affects the radiation budget, which controls summer melt and thereby summer mass balance. Therefore, detailed knowledge of the spatial and temporal distributions of snowfall on glaciers is essential for satisfactory performance of glacier mass balance models (Liston et al. 1994; Hanssen-Bauer \& Førland 1998; Fettweis et al. 2008; Adhikari \& Huybrechts 2009; Aas et al. 2016; Van Pelt et al. 2016). The meteorological forcing used in such models is typically derived from nearby meteorological station records, from outputs of a regional climate model or general circulation model, or from reanalysis datasets (Lang et al. 2015; Van Pelt \& Kohler 2015; Østby et al. 2017). Regional climate models and general circulation models can provide insights into snow precipitation over large areas, but snowfall varies substantially at smaller spatial scales (Bromwich et al. 2004; Schuler et al. 2008). Snow accumulates from direct snowfall, from wind-blown snow or, most often, from a combination of the two processes. Snowfall is strongly affected by topography, which is too coarsely represented in large-scale models to resolve its variability (Smith \& Barstad 2004; Barstad \& Smith 2005; Crochet et al. 2007; Schuler et al. 2008). In situ records of snow accumulation are useful for understanding spatiotemporal variability and may provide valuable means for 
evaluating the performance of atmospheric models away from synoptic stations.

In the glaciological method (Zemp et al. 2013), mass balance is measured by repeatedly measuring the emergence of stakes fixed into the ice. Typically, stakes are measured twice a year, that is, at the end of the winter accumulation season and again at the end of the ablation period. When possible, the precipitation forcing used in a mass balance model can be modified using correction factors, to match in situ observations (Hanssen-Bauer $\&$ Førland 1998; Van Pelt et al. 2016). However, a question remains regarding how well precipitation timing and spatial variability are represented on shorter timescales. This can be important, for example, in evaluating the simulation of surface albedo or snow accumulation process in the time steps of a mass balance model (Pramanik et al. 2018).

Long-term and accurate in situ measurement of individual snowfall events is a challenge for any automated measurement. Even when personnel are available for maintenance, the horizontal, wind-induced transport of snow impedes accurate measurement of precipitation (Braaten 2000) and corrections are difficult to apply, if at all possible (Wolff et al. 2015). There are a number of ways to autonomously record snow in situ, including snow pillows, weighing precipitation gauges and AWSs equipped with sonic rangers to detect snow surface elevation changes (Oerlemans 2001). All have drawbacks for unattended long-term monitoring; for example, internal ice layers impact measurements using snow pillows (Sorteberg et al. 2001), and precipitation gauges are significantly affected by wind (Førland \& Hanssen-Bauer 2000; Ryan et al. 2008; Duchon et al. 2014; Mekonnen et al. 2015; Wolff et al. 2015). Sonic ranger measures snow depth evolution; it can provide valuable information about accumulation and snowfall temporal variability, but separating the signal into wind-driven accumulation and snowfall remains an issue. There are other, more sophisticated methods for measuring snow, which can distinguish wind-driven accumulation and snow precipitation (Castellani et al. 2015), but these are typically expensive and require manual observations, frequent supervision and maintenance.

Sonic rangers have been widely used (Braaten 2000; Bromwich \& Fogt 2004; Cohen \& Dean 2013; Castellaniet al. 2015) to characterize solid precipitation and surface mass balance on sub-annual timescales and to identify individual accumulation events. Sonic rangers gauge snow surface height; positive changes thereof can be related to the accumulation of snow at the site, but do not indicate whether snow accumulation is due to solid precipitation or advection as wind-driven snow (Braaten 2000). Wind-driven snow redistribution (erosion and deposition) remains a significant and ongoing challenge for studying snow on the ground since the process is complex and depends on many factors besides wind speed, such as topographical exposure and snow properties (e.g., hardness, moisture and grain size) (Li \& Pomeroy 1997; Essery et al. 1999; Dery \& Yau 2001; Lenaerts et al. 2014). Precipitation at the synoptic scale often occurs concurrently with high wind speeds, which can lead to an increase or decrease in snow height (Bromwich 1988) over short length scales. Wind-stress in polar regions frequently exceeds the shear strength of the snowpack, causing snow particles to be transported as blowing or drifting snow (Knuth et al. 2010). Snowfall, blowing snow, hoar frost deposition, surface sublimation, wind-induced compaction, wind erosion, snow settling, rainfall or any combination of these factors can cause changes, positive and negative, in snow height (Li \& Pomeroy 1997). Consequently, changes in snow surface height cannot be unambiguously associated with a single mechanism (Knuth et al. 2010). Nevertheless, valuable information about accumulation and snowfall variability can be derived by complementing snow surface height measurements with additional meteorological observations (Ryan et al. 2008; Knuth et al. 2010; Cohen \& Dean 2013).

The goal of this article is to evaluate the precipitation forcing to be used in a mass balance model for the glacierized area of Kongsfjorden basin in north-western Svalbard (Pramanik et al. 2018) through comparison with in situ data obtained on two of the glaciers in the study area. ERA-Interim reanalysis data set (Dee et al. 2011) from the European Centre for Medium-Range Weather Forecasts and meteorological station data from Ny-Ålesund are used to find a better precipitation forcing.

Precipitation has been previously studied in the Kongsfjord area, mostly near the research town of Ny-Ålesund (Førland \& Hanssen-Bauer 2000, 2003; Førland et al. 2011), while Hanssen-Bauer \& Førland (1998) and Van Pelt et al. (2016) address solid and liquid precipitation amounts and trends over all of Svalbard. Here we investigate snow precipitation and accumulation on two glaciers in the area of Kongsfjorden in north-western Svalbard to study the inter-station variability of accumulation and snowfall considering wind (drift) conditions. Our in situ snow surface height data are recorded at two AWSs located on two glaciers in the Kongsfjord area. We also use auxiliary meteorological data (temperature, wind speed and wind direction) from the AWSs to filter snow accumulation events, thereby distinguishing SC from SW. We then compare the identified snowfall events at the glacier sites to coincident events in the ERAInterim and Ny-Ålesund records. 


\section{Study site and data}

\section{Site and basic climatology}

Kongsfjorden is situated in the north-west part of Svalbard. It is surrounded by glaciers (Fig. 1); those on the eastern and northern sides of the fjord are mostly large $\left(>50 \mathrm{~km}^{2}\right)$ tidewater glaciers, whereas those on the southern side are relatively small $\left(<10 \mathrm{~km}^{2}\right)$ land-terminating glaciers (http://toposvalbard.npolar.no/). Two of the larger tidewater glaciers-Holtedahlfonna glacier (HDF) (ca. $400 \mathrm{~km}^{2}$ ) and Kongsvegen glacier (KNG) (ca. $100 \mathrm{~km}^{2}$ ) (Fig. 1) - are sites of extensive and longterm glacier mass balance monitoring by the Norwegian Polar Institute (www.mosj.no/en/climate/land/mass-balance-glaciers.html).

Most snowfall in Svalbard is produced by cyclonic activity, which peaks in autumn and winter. This seasonal precipitation cycle is associated with the increase in cyclone activity along the North Atlantic storm track during autumn and winter (Tsukernik et al. 2007;
Sorteberg \& Walsh 2008; Osuch \& Wawrzyniak 2017). These storm systems typically travel northward towards the Arctic in the Greenland Sea and approach Svalbard from the south/south-west (Serreze et al. 1993; Walsh et al. 1994; Rogers et al. 2001; Førland et al. 2011; Kaesmacher \& Schneider 2011), bringing precipitation, widespread cloudiness and strong winds. Based on these patterns, we would expect KNG to have more snow and especially more drifting or blowing snow events than $\mathrm{HDF}$, due to KNG's orientation and higher exposure to southerly winds.

Cohen (unpubl. data) shows that for the North Atlantic sector of the Arctic (including Svalbard), 80-90\% of the total precipitation occurs during these synoptic events. This is important because most of the widely used reanalysis data sets reproduce synoptic variability well (Simmonds et al. 2012). Specifically, ERA-Interim has been shown (Cohen unpubl. data) to have good correlation $(r=0.64)$ with Ny-Ålesund observations and a near-zero bias.

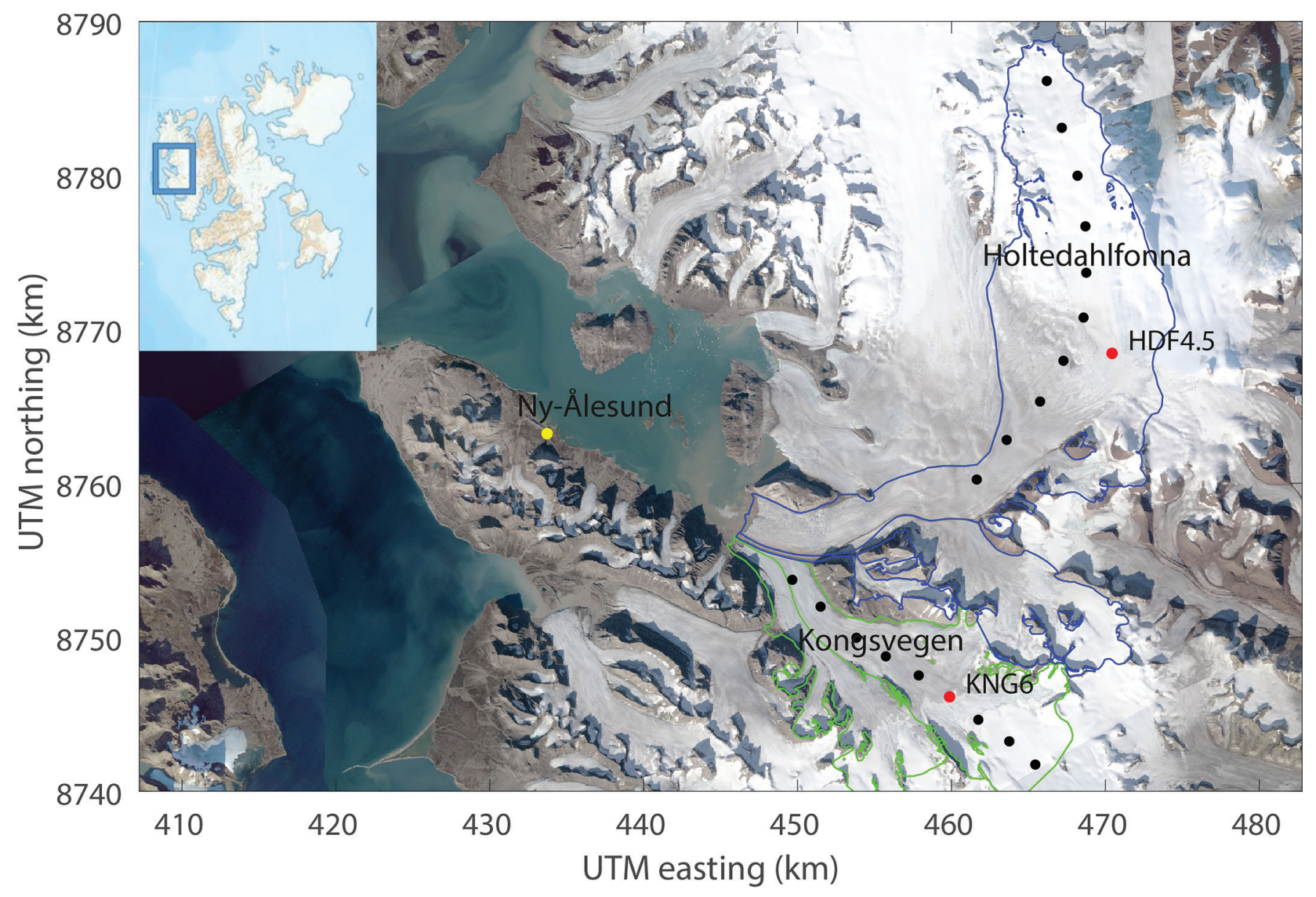

Fig. 1 Locations of AWSs (red dots), mass balance measurement stakes (black dots) and Ny-Ålesund meteorological station (yellow dot). KNG and HDF are shown with green and blue outlines, respectively. 


\section{Glacier AWS data}

AWSs were installed on KNG, at stake 6 (KNG6) and on HDF, at stake 4.5 (HDF4.5) in 2007 and 2009, respectively (Fig. 1, Table 1). We limit our study to the period 2012-16 because of significant data gaps at various times outside of this period. The straightline distance between these two sites is $24.5 \mathrm{~km}$, while the distances from Ny-Ålesund to KNG6 and HDF4.5 are $36.5 \mathrm{~km}$ and $31.0 \mathrm{~km}$, respectively. Both sites are situated in the upper ablation zone of their respective glaciers, near their present-day equilibrium lines.

The AWSs record meteorological data air temperature, wind speed, wind direction, incoming and outgoing shortwave and longwave radiation, relative humidity at hourly intervals. The sensors are nominally located $2 \mathrm{~m}$ above the ice surface; this distance, however, varies throughout the winter as the snow amount changes. The AWSs also include sonic ranger sensors (Campbell Scientific, model SR50A), which measure distance to the snow surface using the two-way travel time of an acoustic pulse. The sensors have a producer-specified resolution and accuracy of 0.0001 and $0.01 \mathrm{~m}$, respectively. The sonic rangers are mounted on separate stakes drilled into the glacier ice, to provide an absolute reference frame. Each spring the sonic rangers are adjusted to sit ca. $0.5-1 \mathrm{~m}$ above the snow surface, and during summer this distance increases by $1-3 \mathrm{~m}$, depending upon local melt rates. Specifications of the sensors are given in Table 2 .

We analyse sonic ranger data over the period 2012-16, but only for periods during which data were available at both sites. We exclude HDF4.5 data from 1 May 2014 to 30 April 2015 since KNG6 had no data in that period (Fig. 2). The remaining data set includes three accumulation seasons, covering the periods 1 May 2012-30 April 2014, and 1 May 2015-1 May 2016.

Table 1 AWS locations (UTM 33X) and elevations.

\begin{tabular}{lccc}
\hline Station & Easting $(\mathrm{m})$ & Northing $(\mathrm{m})$ & Elevation (m.a.s.I.) \\
\hline HDF4.5 & 470471 & 8768404 & 684 \\
KNG6 & 459898 & 8746108 & 534 \\
\hline
\end{tabular}

Table 2 Specifications of the sensors used in this study.

\begin{tabular}{|c|c|c|c|}
\hline Variable & Instrument & $\begin{array}{l}\text { Measurement } \\
\text { range }\end{array}$ & Accuracy \\
\hline Snow (ice) & Campbell SR 50A & 0.5 to $10 \mathrm{~m}$ & $0.01 \mathrm{~m}$ or $0.4 \%$ \\
\hline \multicolumn{4}{|l|}{ Surface height } \\
\hline Temperature & Vaisala HMP45C & $-40^{\circ} \mathrm{C}$ to $+60^{\circ} \mathrm{C}$ & $0.3^{\circ} \mathrm{C}$ \\
\hline Wind speed & Young 05103 & 1 to $60 \mathrm{~ms}^{-1}$ & $0.3 \mathrm{~ms}^{-1}$ \\
\hline Wind direction & Young 05103 & $360^{\circ}$ & $3^{\circ}$ \\
\hline
\end{tabular}

\section{ERA-Interim data}

Global reanalyses assimilate satellite data and in situ meteorological data into a global circulation model to produce comprehensive global data sets of meteorological variables at regular spatial and temporal resolution. Here we use precipitation data from ERA-Interim (Dee et al. 2011 ), which provides data on a ca. $80-\mathrm{km}$ horizontal grid and at 6-hourly intervals, from 1979 to the present. The precipitation data were downscaled to a $1-\mathrm{km}$ grid in a previous study (Østby et al. 2017); here we choose the 1-km grid points that are closest to HDF4.5 and KNG6, located $340 \mathrm{~m}$ and $315 \mathrm{~m}$ distant, and at $697 \mathrm{~m}$ and 537 m elevation, respectively. The ERA-Interim precipitation data set is shown in Fig. 2.

\section{Ny-Ålesund precipitation data}

The closest manned meteorological station to our study area is in Ny-Ålesund. Precipitation is measured at the station in a rain gauge, which is emptied twice daily at 0600 and 1800 UTC. Previous studies showed that high wind concurrent with precipitation events leads to gauge undercatch, reducing the amount of precipitation measured (Førland \& Hanssen-Bauer 2000). Førland \& Hanssen-Bauer (2000) proposed a winddependent correction factor; however, such corrections are not appropriate for all conditions (especially wind speeds greater than $6 \mathrm{~m} \mathrm{~s}^{-1}$ ) and must be applied with care (Sugiura et al. 2006). Therefore, we do not apply a correction factor, and simply use the unadjusted precipitation data.

\section{Snow depth data}

The mass balance of HDF and KNG is measured twice a year (in spring and autumn) to yield winter and summer balances. In addition to the stake measurements previously mentioned, snow depths are measured along transects during the spring campaign to determine the spatial variability of the winter snow accumulation. Snow depth probing at KNG is made on a 500-m grid over most of the glacier surface, while at HDF this is done at $500-\mathrm{m}$ intervals along the glacier centreline. These data are used together with the time-series analysis of the sonic ranger data to evaluate how well the two study sites represent the overall accumulation on the glaciers.

\section{Methods}

We define accumulation events in the sonic ranger data as the occurrence of a significant increase in snow height over a certain period. We divide events into two 

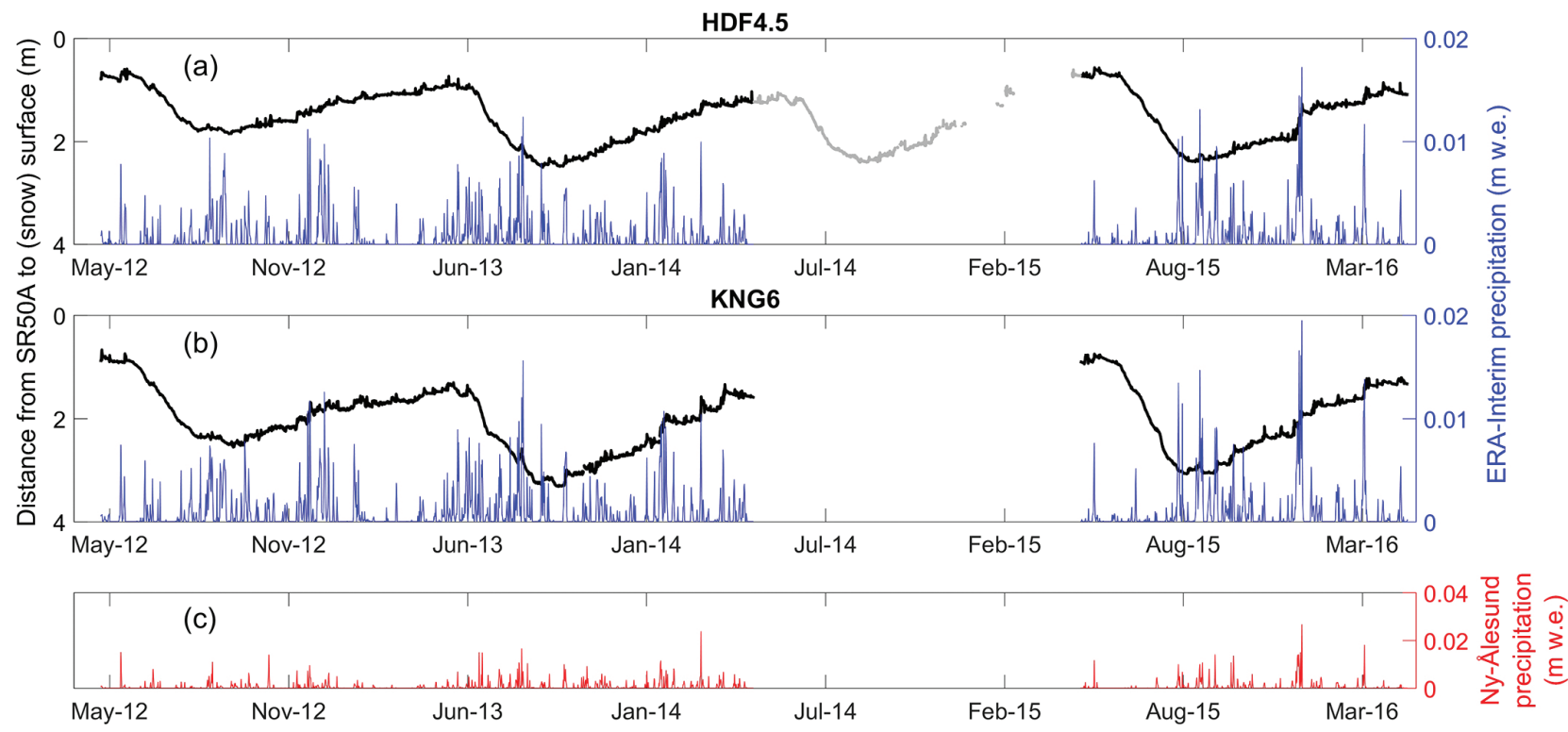

Fig. 2 Sonic ranger data for the two sites (a) HDF4.5 and (b) KNG6 along with ERA-Interim ranalyses precipitation data from nearby grids. Increasing snow surface height represents accumulation and decreasing height is ablation. Data are missing at KNG6 in winter $2014 / 15$ and therefore are excluded for HDF4.5 (shown in grey). (c) Ny-Ålesund precipitation.

categories: accumulation with low wind and accumulation with high wind. We assume that accumulation events with low wind speeds are solely due to snowfall, which we term SC. Accumulation events accompanied by high winds can involve snowfall, erosion and redistribution, which we term SW. We do not consider overall decreases in snow height, which can be due to erosion, compaction, sublimation and snowmelt. These are longer timescale processes, particularly compaction, compared to the typical duration of the accumulation events, and are furthermore not the objective of this study.

\section{Categorize accumulation events}

The hourly sonic ranger record included some noisesmall spikes in the data-which may have been caused by short-lived changes in snow height from deposition or subsequent erosion due to the wind, the acoustic signal being affected by blowing snow particles or instrumental error (Fountain et al. 2010). Any obvious outliers in the sonic ranger data were eliminated first. Then we reduced noise by smoothing the hourly data using a 6-hour running-mean filter (Fountain et al. 2010). We then computed snow height changes $\Delta d(t)$ as the sum of non-zero increases in snow surface height within 12-hour periods. Finally, accumulation events $A c c(t)$ were determined as those 12-hour changes that exceeded a threshold value using the following equation:

$$
\operatorname{Acc}(t)=\left\{\begin{array}{c}
\Delta d, \Delta d(t) \geq T h \\
0, \Delta d(t) \geq T h
\end{array} .\right.
$$

where $T h$ is the threshold value for accumulation, removing small height changes that could arise from spurious sensor readings. We used primarily $T h=0.01 \mathrm{~m}$ for the analysis and applied $T h=0.001 \mathrm{~m}$ and $0.05 \mathrm{~m}$ to assess the effect of the threshold value on identification of accumulation events.

\section{$A_{\text {sw }}$ and $A_{s c}$}

Here we were interested in differentiating calm snowfall (low wind speed) (SC) from wind-induced accumulation events (high wind speed) (SW). Increases in snow height above the threshold (Eqn. 1) in the absence of wind were assumed to be solely due to snowfall $\left(A_{\mathrm{sc}}\right)$ and the remaining events were defined as accumulation with high wind $\left(A_{s w}\right)$. Our criteria for classifying wind conditions were taken from studies of wind speed thresholds in western Canada (Li \& Pomeroy 1997), also used by Knuth et al. (2010). Li \& Pomeroy (1997) proposed that the average threshold for the initiation of blowing snow, as measured at $10 \mathrm{~m}$, is $7.7 \mathrm{~m} \mathrm{~s}^{-1}$ for dry snow transport and $9.9 \mathrm{~m} \mathrm{~s}^{-1}$ for wet snow transport, while the lowest 
wind speed for drifting snow is $4 \mathrm{~m} \mathrm{~s}^{-1}$ for dry snow and $7 \mathrm{~m} \mathrm{~s}^{-1}$ for wet snow. Here we used the drifting snow threshold to differentiate between SC and SW. We used a temperature threshold of $-2^{\circ} \mathrm{C}$ to differentiate between wet and dry snow (Wolff et al. 2015). We characterized the wind speed WS12 for each 12-hour interval, using the maximum of the wind speeds corresponding to the snow surface height increase, while for air temperature T12 and wind direction, we simply took their period means.

AWS station sensors are at variable heights above the snow surface because of increasing snow height through the winter, and none of the sensors is higher than $3 \mathrm{~m}$. In the absence of near-surface wind profile data, we nevertheless applied the aforementioned 10-m wind thresholds. We identified and quantified accumulation events that were solely due to snowfall (SC) $A_{s c}$ as:

$$
\begin{aligned}
A_{s c}= & A c c \text { for } T 12<-2^{\circ} \mathrm{C}, \text { WS } 12<4 \mathrm{~m} \mathrm{~s}^{-1} \text { and } \\
& T 12>-2^{\circ} \mathrm{C}, \text { WS } 12<7 \mathrm{~m} \mathrm{~s}^{-1},
\end{aligned}
$$

and accumulation with high wind $A_{\text {sw }}$ as:

$$
\begin{gathered}
A_{s w}=\text { Acc for } T 12<-2^{\circ} \mathrm{C}, \text { WS } 12>4 \mathrm{~m} \mathrm{~s}^{-1} \text { and } \\
\text { T12 }>-2^{\circ} \mathrm{C}, \text { WS } 12>7 \mathrm{~m} \mathrm{~s}^{-1} .
\end{gathered}
$$

The number of events corresponding to $A_{s c}$ and $A_{s w}$ are denoted by $n A_{s c}$ and $n A_{s w^{\prime}}$ respectively.

We used the density of snow for calm snowfall events following the formula proposed by Pomeroy et al. (1998) to calculate snow accumulation in m.w.e. for comparison with ERA-Interim and Ny-Ålesund precipitation:

$$
\rho_{\text {fresh }}=67.9+51.3 e^{T / 2.6}
$$

while the density of fresh snow for high-wind events was set to $250 \mathrm{~kg} \mathrm{~m}^{-3}$ (Pomeroy et al. 1998).

\section{Determination of coincident events}

We evaluated whether SC and SW events at glacier sites coincided with modelled precipitation using the ERAInterim reanalysis data and measured precipitation in Ny-Ålesund. Twelve-hour accumulation totals at the glacier sites were calculated over the same periods as the individual precipitation observations measured in Ny-Ålesund, and over the same time intervals as a 12-hour summed version of the ERA-Interim amounts. The corresponding $A_{s c}$ and $A_{s w}$ amounts were compared with ERA-Interim and Ny-Ålesund precipitation to find root mean square error (RMSE) and biases. We further calculate the number of coincident events with ERA-Interim and Ny-Ålesund for the different accumulation thresholds.

\section{Results and discussion}

\section{Accumulation variability at two sites}

The total number of all identified accumulation events $\left(n A_{\text {sc }}+n A_{\text {sw }}\right)$ (Table 3 ) was 429 and 537 over the study period for HDF4.5 and KNG6, respectively, indicating that there are more events at KNG than at HDF, and the events are dominated by $n A_{s w}$ at both sites rather than $n A_{s c}$. Figure 3 shows the total accumulation, and

Table 3 Total number of accumulation events $(N)$ and percentage of total accumulation events caused by SC $\left(n A_{s c}\right)$ and $S W\left(n A_{s w}\right)$ for accumulation threshold $0.01 \mathrm{~m}$.

\begin{tabular}{lccc}
\hline Sites & $N$ & $n A_{s c}(\%)$ & $n A_{s w}(\%)$ \\
\hline HDF4.5 & 429 & 38 & 62 \\
KNG6 & 537 & 19 & 81
\end{tabular}

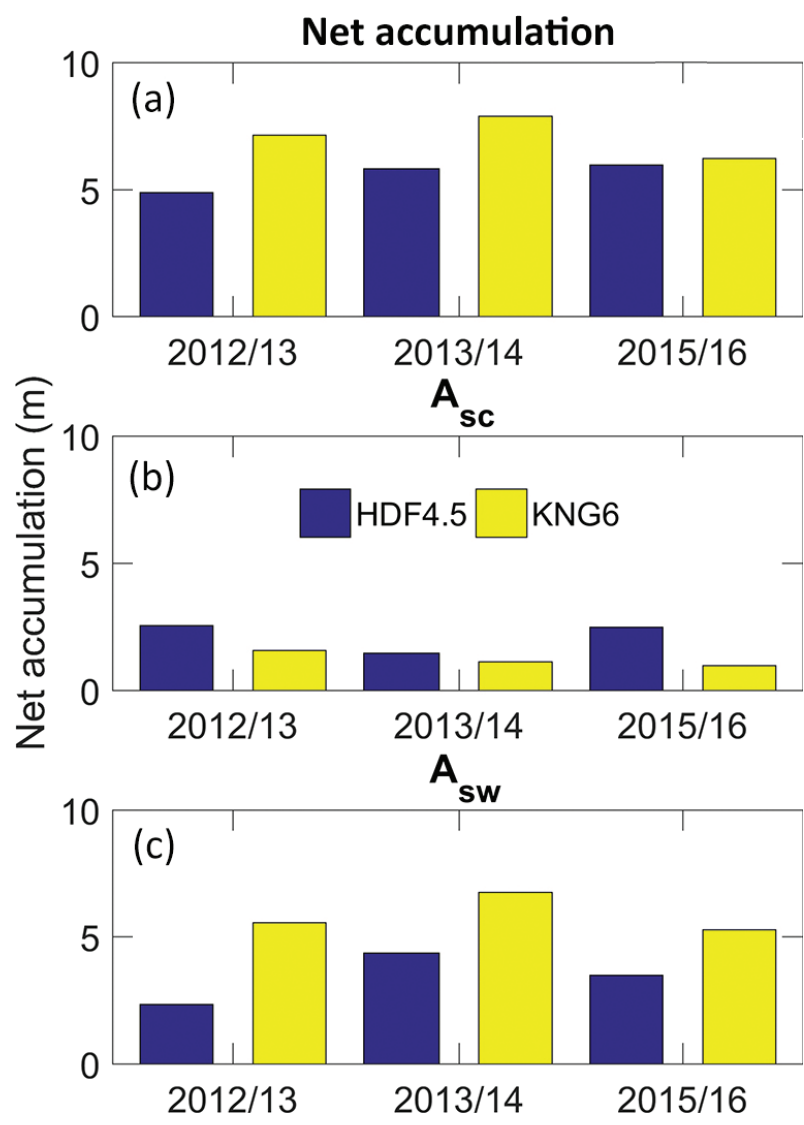

Fig. 3 Summed accumulation for three years for (a) net accumulation, (b) SC and (c) SW at both the sites. Most accumulation events are associated with high wind. The total amount of accumulation at KNG6 is, on average, $36 \%$ higher than HDF4.5. 
$A_{\mathrm{sc}}$ and $A_{\mathrm{sw}^{\prime}}$ for three different years at both sites. Net accumulation at KNG6 was about $36 \%$ higher than at HDF4.5. $A_{\text {sc }}$ was $43 \%$ less at KNG6 than at HDF4.5, and $A_{\text {sw }}$ at KNG6 was, on average, $75 \%$ more than at HDF4.5.

Most of the accumulation events at KNG6 were associated with high wind speeds. It is not possible with the sonic ranger data alone to unequivocally state whether an accumulation event with high wind was accompanied by snowfall. In general, however, the larger the magnitude of the event, the more likely it is that at least some snowfall is involved (Knuth et al. 2010; Cohen \& Dean 2013; Castellaniet et al. 2015). Figure 4 shows histograms associated with the accumulation events at both sites. The prevailing wind speed during accumulation events was lower at HDF4.5, with a median value of $4.1 \mathrm{~m} \mathrm{~s}^{-1}$, than at KNG6, where the median value was $5.7 \mathrm{~m} \mathrm{~s}^{-1}$. This difference in wind speeds between the two sites was larger than what can be explained by the difference in sensor heights, which rarely exceeds $2 \mathrm{~m}$. In spite of its lower elevation, KNG6 accumulated more snow than HDF4.5. This may be because of the prevailing wind directions at the two sites. At HDF4.5, the prevailing wind direction during snowfall was in the downglacier direction (Fig. 5a), from the north-north-east, whereas at KNG6 the bulk of snowfalls coincided with wind from the south-south-east (Fig. 5b). Air masses from the north are generally colder and associated with less precipitation. In addition, KNG6 is closer to the open sea. Both factors partly explain the difference in accumulation amounts between the two sites.

Accumulation events occurring above $2{ }^{\circ} \mathrm{C}$ could have been due to mixed precipitation, but it was not possible to differentiate such events. Uncertainty in defining events can arise from the choice of wind and air temperature thresholds; the values we used were taken from previous studies, and thresholds may vary in space and time. Figure 6 shows the snow depth data at both glaciers, which confirms that KNG overall receives more snow than HDF. We found a greater difference in snow accumulation between HDF4.5 and KNG6 in the years 2012/13 and 2013/14 compared to the difference between the two sites in 2015/16 (Fig. 3). A similar result was observed from snow depth data at these two glaciers and at their respective AWS sites. The difference in snow depth measured by snow depth probing at the end of the winter at the two AWs locations was comparable to snow accumulation measured from sonic ranger data. The accumulation measured at the two study sites can therefore be regarded representative of the glaciers.
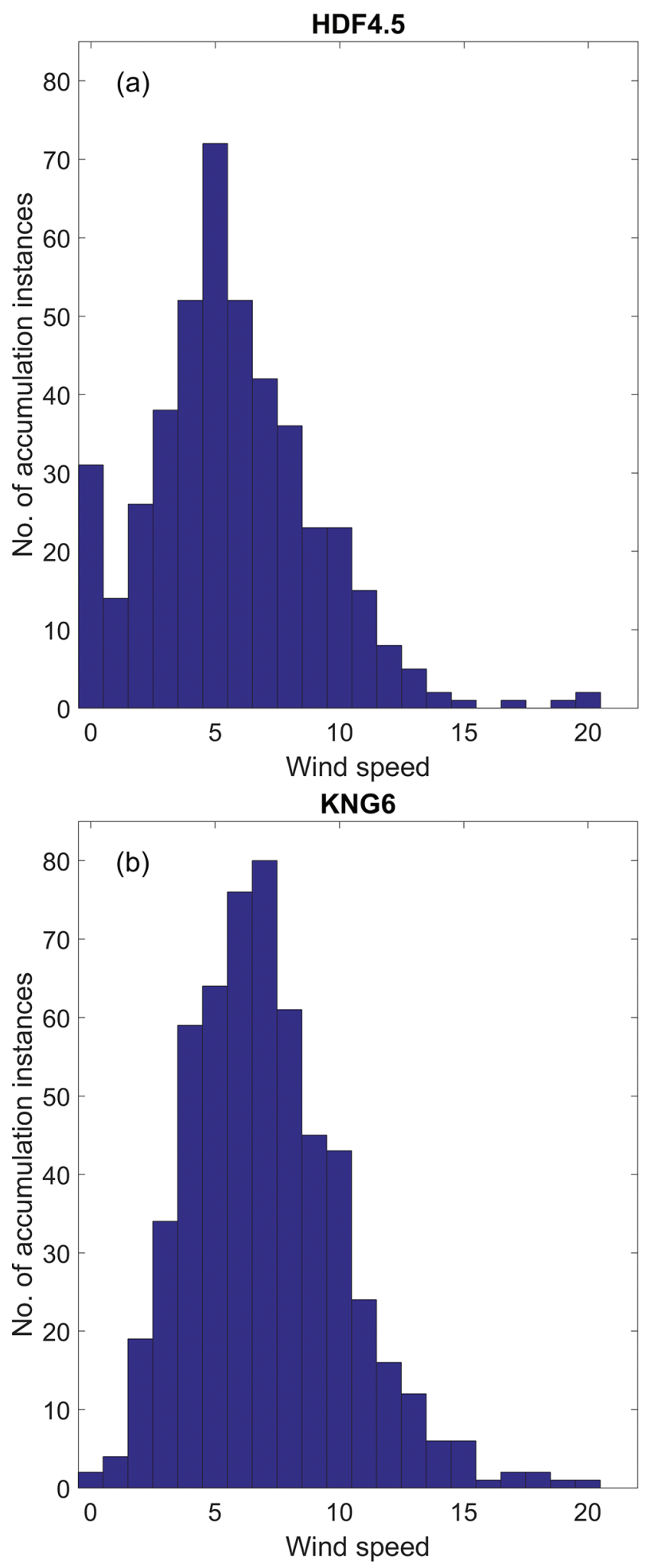

Fig. 4 Number of accumulation events for different wind speeds: (a) HDF4.5 and (b) KNG6. Most events in HDF4.5 occurred with wind speed of 4 to $8 \mathrm{~m} \mathrm{~s}^{-1}$, whereas in KNG6 most events occurred with 5 to $10 \mathrm{~m} \mathrm{~s}^{-1}$ wind speed. 


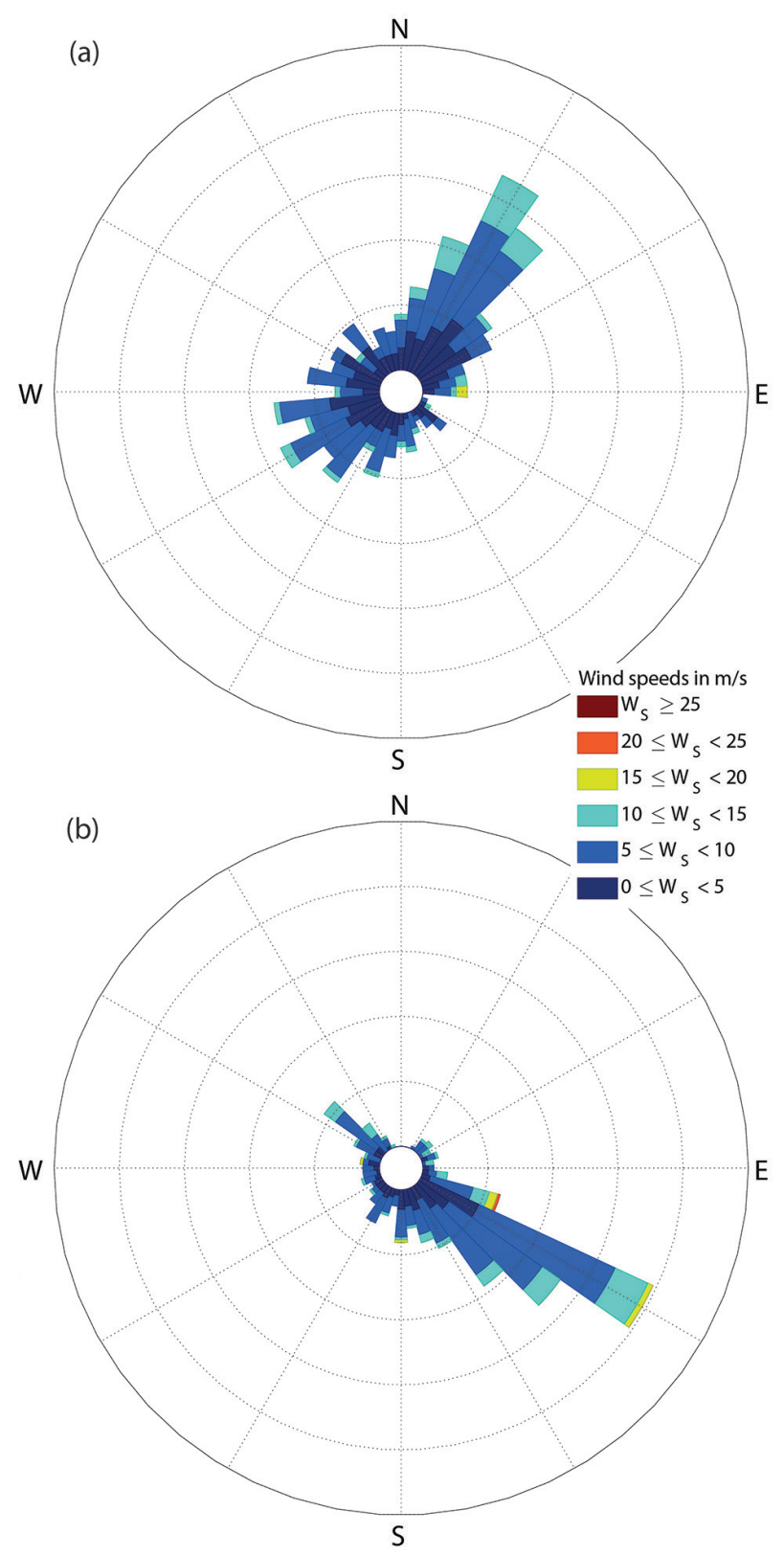

Fig. 5 (a) Wind speed and direction for all accumulation events at HDF4.5. Prevailing wind direction is northerly and north-easterly. (b) Wind speed and direction for accumulation events at KNG6 for all accumulation events. Prevailing wind direction is the direction of the katabatic wind.

\section{Correlation to precipitation forcing data}

\section{Comparison of coincident precipitation events}

Table 4 shows the percentages of glacier SC and SW events seen in the ERA-Interim and Ny-Ålesund precipitation records. While the number of coincident events with ERA-Interim and Ny-Ålesund data for SC was comparable $(72-80 \%$ coincident events), there was a significant difference in the number of coincident events for SW between ERA-Interim and Ny-Ålesund; ERA-Interim had $17 \%$ and $15 \%$ more coincident events than at HDF4.5 and KNG6, respectively, compared to Ny-Ålesund. This suggests that the ERA-Interim record captures more events occurring at the study sites and is, therefore, more likely to provide a reasonable representation of precipitation on the glaciers.

That ERA-Interim captured more of the observed SW and SC events on the glaciers than the Ny-Ålesund record may be due to a number of reasons. The distance between the Ny-Ålesund precipitation gauge and the glacier stations is larger than the distances between the sites and those between sites and their closest ERA Interim grid points. Similarly, the elevation differences between Ny-Ålesund and the study sites (634 m for HDF4.5 and $484 \mathrm{~m}$ for KNG6) are much larger than those between ERA-Interim grid points and study sites ( $7 \mathrm{~m}$ for HDF4.5 and $3 \mathrm{~m}$ for KNG6). In addition, the Ny-Ålesund gauge site, which is located close to sea level and in a built-up area, has a significantly different topographic setting than the glacier AWSs, and is considerably more exposed to north-westerly airflow than the glacier sites (Fig. 1). Finally, the precipitation records at Ny-Ålesund are considerably affected by wind-caused undercatch (Førland \& Hanssen-Bauer 2000), in contrast to the sonic ranger records.

Table 5 shows the sensitivity of coincident accumulation events at the AWS sites and the ERA-Interim and Ny-Ålesund records, applying the different accumulation thresholds $(0.001 \mathrm{~m}, 0.005 \mathrm{~m}$ and $0.01 \mathrm{~m}$ per 12-hourly period). Not surprisingly, decreasing the AWS accumulation threshold increased the total number of accumulation events, but decreased the percentage of coincident events, which indicates that both ERA-Interim and Ny-Ålesund precipitation data captured most of the largest accumulation events. For both accumulation thresholds, ERA-Interim captured more coincident events than Ny-Ålesund, and the percentage of coincident events decreased more for Ny-Ålesund than for ERA-Interim.

\section{Comparison of coincident precipitation amount}

Figure 7 shows a comparison of $A_{s c}$ and $A_{s w}$ for the corresponding coincident events at the AWS sites to those in the ERA-Interim and with Ny-Ålesund records, with reduced major axis regression correlations ( $r$ values are significant at a $90 \%$ confidence level according to Student's t-test). Correlation of HDF4.5 amounts to ERAInterim and Ny-Ålesund precipitation was better than KNG6 during calm events. There was better agreement of $A_{s w}$ between KNG6 and ERA-Interim than between 

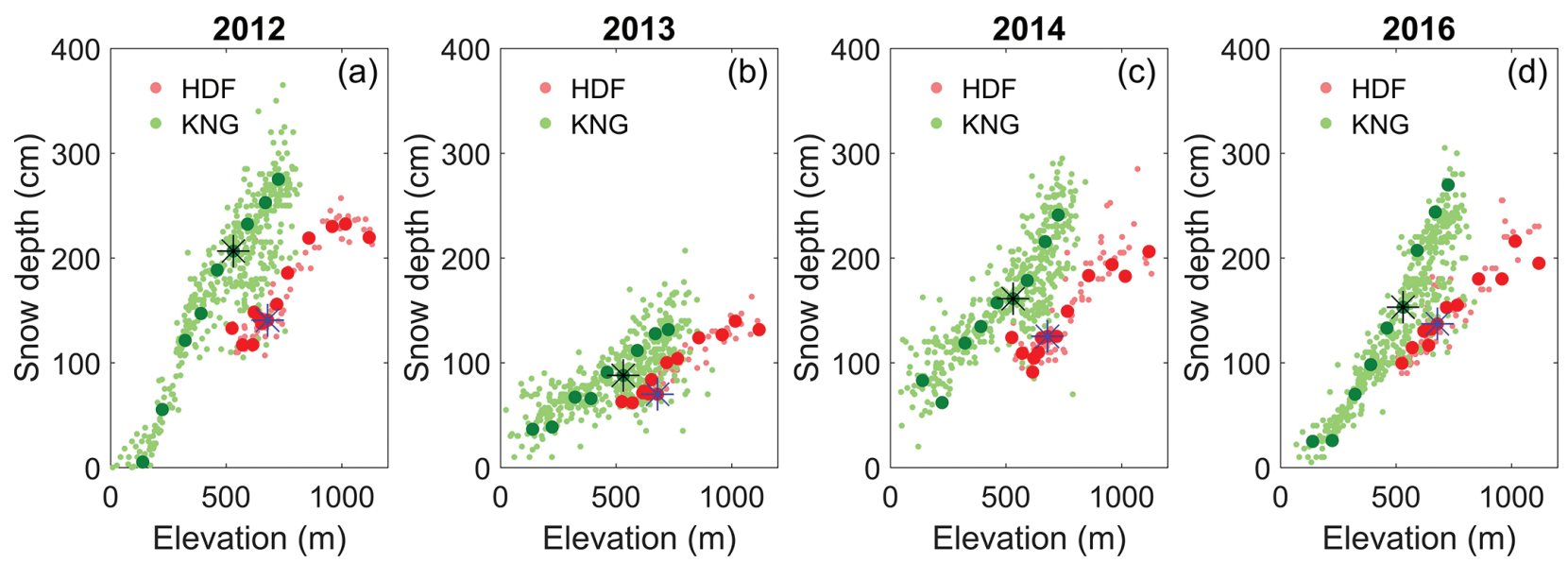

Fig. 6 Snow depth data measured by snow probe at KNG and HDF in (a) 2012, (b) 2013, (c) 2014 and (d) 2016. Snow depth is measured at 500-m intervals along the centreline of HDF, while at KNG snow depths are measured on a 500-m grid. Large circles are the snow depths at the locations of the mass balance stakes. Depths at the two AWS site locations are shown with asterisks.

Table 4 Percentage of calm snowfall events (SC) events and high-wind accumulation events (SW) events at glacier sites coincident with precipitation of ERA-Interim and Ny-Ålesund.

\begin{tabular}{lcclccc}
\hline & \multicolumn{3}{c}{ SC } & & \multicolumn{2}{c}{ SW } \\
\cline { 2 - 3 } \cline { 5 - 6 } \cline { 5 - 6 } & HDF 4.5 (\%) & KNG 6 (\%) & & HDF 4.5 (\%) & KNG 6 (\%) \\
\hline ERA-Interim & 80 & 75 & & 73 & 67 \\
Ny-Ålesund & 74 & 72 & & 56 & 52 \\
\hline
\end{tabular}

Table 5 Sensitivity of coincident events (\%) between AWS sites and ERA-Interim, and AWS sites and Ny-Ålesund for different accumulation threshold values.

\begin{tabular}{lcccccc}
\hline \multirow{2}{*}{ Threshold (m/12 hour) } & \multicolumn{3}{c}{ SC } & & \multicolumn{2}{c}{ SW } \\
\cline { 3 - 4 } \cline { 6 - 7 } \cline { 6 - 7 } & & HDF 4.5 (\%) & KNG6 (\%) & HDF4.5 (\%) & KNG6 (\%) \\
\hline \multirow{20}{*0.005}{} & ERA-Interim & 65 & 67 & & 70 & 62 \\
& Ny-Ålesund & 57 & 55 & & 61 & 43 \\
& ERA-Interim & 50 & 56 & & 63 & 54 \\
& Ny-Ålesund & 37 & 37 & & 45 & 35 \\
\hline
\end{tabular}

KNG6 and Ny-Ålesund. However, the correlation of $A_{s c}$ at KNG6 was poor for both ERA-Interim and Ny-Ålesund. Table 6 shows the RMSE and relative bias for the event sizes. As expected, for both glacier sites, RMSE and bias for $A_{s c}$ events are much smaller than for $A_{s w}$. The biases for event sizes during $A_{s w}$ were negative at both glacier sites and for both ERA-Interim and Ny-Ålesund, indicating that on-glacier accumulation was greater than the precipitation determined from either the ERA-Interim or the Ny-Ålesund records. These biases and the higher RMSE values for $A_{s w}$ events may be due to a combination of the assumed snow density value or due to redistribution of snow during high-wind events.

Because precipitation amounts were better quantified in SC events at HDF4.5, there was a better agreement for $A_{s c}$ than for $A_{s w}$. Overall, we found that the downscaled ERA-Interim data better capture the occurrence of precipitation events at the AWS sites compared to Ny-Ålesund. However, ERA-Interim and Ny-Ålesund precipitation amounts do not correlate well with the measurements at the glacier sites. The precipitation amounts estimated by ERA-Interim and measured at Ny-Ålesund were

Table 6 RMSE and bias between AWS sites and ERA-Interim, and AWS sites and Ny-Ålesund. Units are in mm w.e. Bias is calculated as deviation from AWS accumulation amount.

\begin{tabular}{|c|c|c|c|c|c|c|c|c|}
\hline & \multicolumn{4}{|c|}{ HDF4.5 } & \multicolumn{4}{|c|}{ KNG6 } \\
\hline & \multicolumn{2}{|c|}{ SC } & \multicolumn{2}{|c|}{ SW } & \multicolumn{2}{|c|}{ SC } & \multicolumn{2}{|c|}{ SW } \\
\hline & RMSE & Bias & RMSE & Bias & RMSE & Bias & RMSE & Bias \\
\hline ERA-Interim & 2 & -0.4 & 8.3 & -5 & 2.8 & 0.3 & 10 & -7.1 \\
\hline Ny-Ålesund & 2.6 & 0.1 & 8.7 & -6 & 2.7 & 0.3 & 10 & -7.8 \\
\hline
\end{tabular}



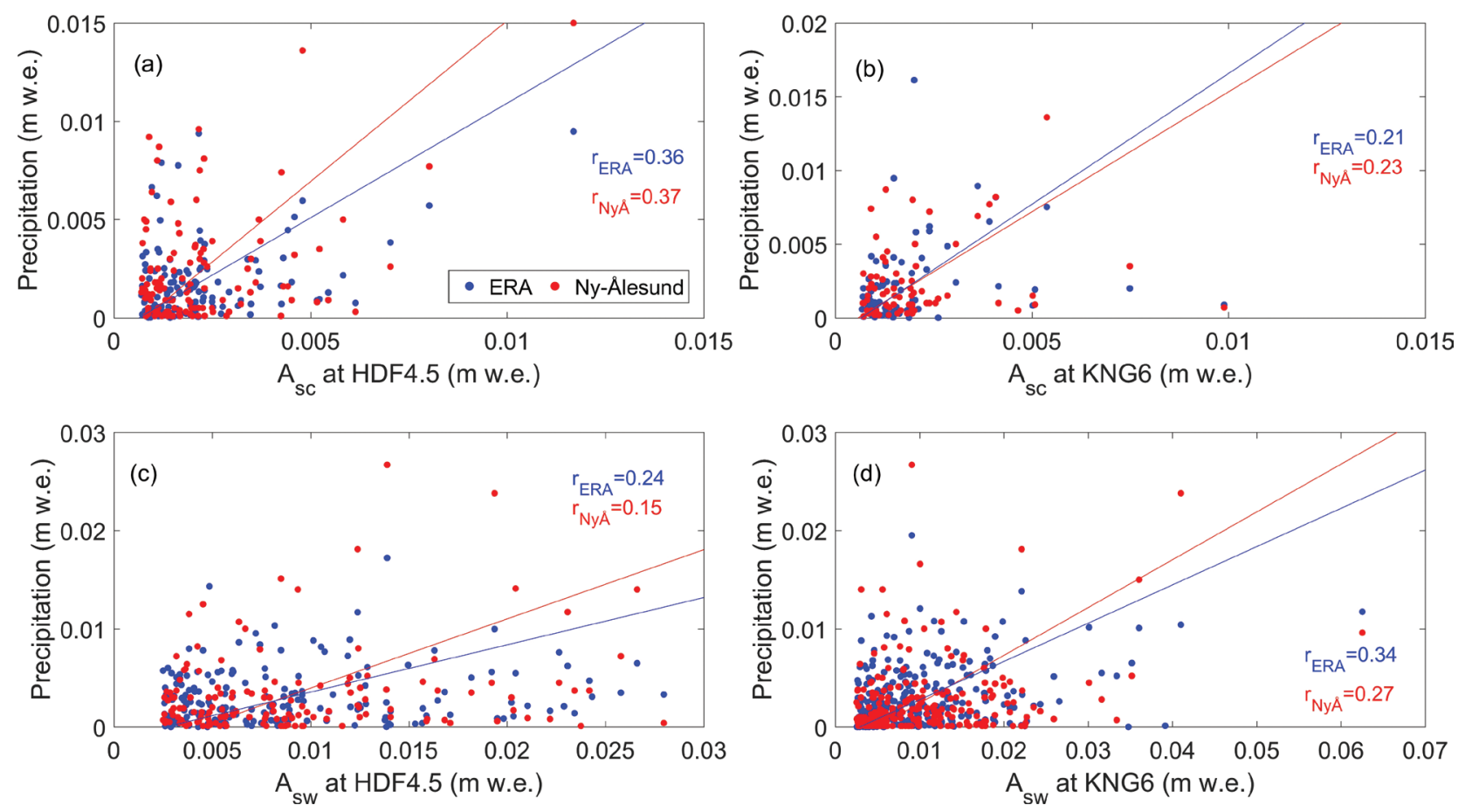

Fig. 7. Comparison of ERA-Interim and Ny-Ålesund precipitation amounts to HDF4.5 and KNG6 snowfall amounts converted to m.w.e. Upper panels (a, b) show correlations for calm events $\left(A_{s c}\right)$ and lower panels $(c, d)$ show correlations for wind events $\left(A_{s w}\right)$.

similar, and RMSE and biases with the AWS measurements were comparable. The relatively large RMSE and biases between both sites and ERA-Interim suggest that modelled precipitation amounts should be used with caution in mass balance models.

\section{Conclusions and outlook}

We used sonic ranger data from two glacier sites on KNG and HDF in Svalbard to investigate snow accumulation events. The sonic rangers measure snow surface height changes; we filtered these data to identify individual snow accumulation events and used air temperature and wind speed data to distinguish accumulation events influenced by wind from those that occurred during calm conditions. Here we were chiefly interested in comparing the snow accumulation measured at glacier sites with precipitation data derived from rain gauges and largescale model simulations. Snow depth changes generally involve a number of complex processes-for example, snow deposition and erosion, and also compaction and sublimation-which are beyond the scope of the longterm aspect of this field-based study. Detailed snowpack modelling would be required to consider such processes (Lehning et al. 2002). The main difficulty in detecting snow accumulation using sonic rangers or similar devices arises when precipitation is concurrent with high winds, which is the case during most Svalbard precipitation events. Nevertheless, information derived from sonic rangers is useful for model evaluation and comparative study among several locations.

Overall, the KNG6 site experienced a higher number of accumulation events and accumulates more snow than HDF4.5, and also experienced higher wind speeds. Hence, the higher winds restricted identification of SCs, according to our definition. In contrast, HDF4.5 was less windy, with more events occurring during calm conditions. The prevailing wind directions during accumulation events were different at the two sites; KNG6 received more precipitation during southerly winds, while HDF4.5 received precipitation predominantly during north-north-easterly winds.

Precipitation events in the downscaled ERA-Interim precipitation data set coincided better with both SWs and SCs at the glacier sites, compared to the Ny-Ålesund precipitation record. However, the agreement is relatively poor for accumulation amounts during coincident events at both sites and the ERA-Interim and Ny-Ålesund records. Large-scale model precipitation provides a more reasonable representation of precipitation events on our study glaciers than does a single, station-based 
precipitation measurement. Comparing time series at two sites with the manual snow depth probing over the glacier, we conclude that using distributed precipitation fields is preferable as a precipitation forcing in a mass balance model.

In this study, we distinguish wind-influenced accumulation from pure snowfall events on synoptic timescales; however, to investigate in more detail the processes of erosion, deposition and precipitation, more frequent, attended and sophisticated measurements would be required, for example, continuous monitoring through Lidar (Deems et al. 2013); this is challenging for unmanned AWS sites. To gain more detailed information on the spatial scale of precipitation events, a denser network of snow sensors would be required.

\section{Acknowledgements}

The authors thank the National Centre for Polar and Ocean Research and the Ministry of Earth Sciences, Government of India, for the PhD funding of the first author. They also thank two anonymous referees for their insightful comments that helped to improve the manuscript. This article is National Centre for Polar and Ocean Research's contribution (no. J-9/2019-20).

\section{Funding}

The first author received PhD studentship support from ESSO-National Centre for Polar and Ocean Research, financed by the Ministry of Earth Sciences, Government of India, under grant/award number MoES/16/22/12RDEAS (PhD fellowship at the Norwegian Polar Institute). Additional funding for this work came from the PolishNorwegian research project Glaciers as Arctic Ecosystem Refugia, the Norwegian Research Council project Tidewater Glacier Retreat Impact on Fjord Circulation and Ecosystems, and the Norwegian Polar Institute project Centre for Ice, Climate and Ecosystems.

\section{Disclosure statement}

The authors report that they have no conflicts of interest.

\section{References}

Aas K.S., Dunse T., Collier E., Schuler T.V., Berntsen T.K., Kohler J. \& Luks B. 2016. The climatic mass balance of Svalbard glaciers: a 10-year simulation with a coupled atmosphere-glacier mass balance model. Cryosphere 10, 1089-1 104, http://dx.doi.org/10.5194/tc-10-1089-2016.
Adhikari S. \& Huybrechts P. 2009. Numerical modelling of historical front variations and the 21st-century evolution of glacier AX010, Nepal Himalaya. Annals of Glaciology 50, 27-34, http://dx.doi.org/10.3189/172756409789624346.

Barstad I. \& Smith R.B. 2005. Evaluation of an orographic precipitation model. Journal of Hydrometeorology 6, 85-99, http://dx.doi.org/10.1175/jhm-404.1.

Braaten D.A. 2000. Direct measurements of episodic snow accumulation on the Antarctic polar plateau. Journal of Geophysical Research-Atmospheres 105, 10119-10128, http://dx.doi.org/10.1029/2000jd900099.

Bromwich D.H. 1988. Snowfall in high southern latitudes. Reviews of Geophysics 26, 149-168, http://dx.doi.org/10.1029/ RG026i001p00149.

Bromwich D.H. \& Fogt R.L. 2004. Strong trends in the skill of the ERA-40 and NCEP-NCAR reanalyses in the high and midlatitudes of the Southern Hemisphere, 1958-2001. Journal of Climate 17, 4603-4619, http://dx. doi.org/10.1175/3241.1.

Bromwich D.H., Guo Z.C., Bai L.S. \& Chen Q.S. 2004. Modeled Antarctic precipitation. Part I: spatial and temporal variability. Journal of Climate 17, 427-447, http://dx.doi. org/10.1175/1520-0442(2004)017<0427:mappis>2.0.c0;2.

Castellani B.B., Shupe M.D., Hudak D.R. \& Sheppard B.E. 2015. The annual cycle of snowfall at Summit, Greenland. Journal of Geophysical Research-Atmospheres 120, 6654-6668, http://dx.doi.org/10.1002/2015jd023072.

Cohen L. \& Dean S. 2013. Snow on the Ross Ice Shelf: comparison of reanalyses and observations from automatic weather stations. The Cryosphere 7, 1399-1410, http://dx. doi.org/10.5194/tc-7-1399-2013.

Crochet P., Johannesson T., Jonsson T., Sigurdsson O., Bjoensson H., Palsson F. \& Barstad I. 2007. Estimating the spatial distribution of precipitation in Iceland using a linear model of orographic precipitation. Journal of Hydrometeorology 8, 1285-1306, http://dx.doi. org/10.1175/2007jhm795.1.

Dee D.P., Uppala S.M., Simmons A.J., Berrisford P., Poli P., Kobayashi S., Andrae U., Balmaseda M.A., Balsamo G., Bauer P., Bechtold P., Beljaars A.C.M., Van De Berg L., Bidlot J., Bormann N., Delsol C., Dragani R., Fuentes M., Geer A.J., Haimberger L., Healy S.B., Hersbach H., Holm E.V., Isaksen L., Kallberg P., Koehler M., Matricardi M., Mcnally A.P., Monge-Sanz B.M., Morcrette J.J., Park B.K., Peubey C., De Rosnay P., Tavolato C., Thepaut J.N. \& Vitart F. 2011. The ERA-Interim reanalysis: configuration and performance of the data assimilation system. Quarterly Journal of the Royal Meteorological Society 137, 553-597, http://dx.doi.org/10.1002/qj.828.

Deems J.S., Painter T.H. \& Finnegan D.C. 2013. Lidar measurement of snow depth: a review. Journal of Glaciology 59, 467-479, http://dx.doi.org/10.3189/2013JoG12J154.

Dery S.J. \& Yau M.K. 2001. Simulation of blowing snow in the Canadian Arctic using a double-moment model. Boundary-Layer Meteorology 99, 297-316, http://dx.doi. org/10.1023/a:1018965008049.

Duchon C., Fiebrich C. \& Grimsley D. 2014. Using highspeed photography to study undercatch in tipping-bucket 
rain gauges. Journal of Atmospheric and Oceanic Technology 31, 1330-1336, http://dx.doi.org/10.1175/ jtech-d-13-00169.1.

Essery R., Li L. \& Pomeroy J. 1999. A distributed model of blowing snow over complex terrain. Hydrological Processes 13, 2423-2438, http://dx.doi.org/10.1002/(sici) 1099-1085 (199910) 13:14/15<2423::aid-hyp853>3.0.co;2-u.

Fettweis X., Hanna E., Gallee H., Huybrechts P. \& Erpicum M. 2008. Estimation of the Greenland ice sheet surface mass balance for the 20th and 21 st centuries. Cryosphere 2 , 117-129, http://dx.doi.org/10.5194/tc-2-117-2008.

Førland E.J., Benestad R., Hanssen-Bauer I., Haugen J.E. $\&$ Skaugen T.E. 2011. Temperature and precipitation development at Svalbard 1900-2100. Advances in Meteorology 2011, article no. 893790, http://dx.doi. org/10.1155/2011/893790.

Førland E.J. \& Hanssen-Bauer I. 2000. Increased precipitation in the Norwegian Arctic: true or false? Climatic Change 46, 485-509, http://dx.doi.org/10.1023/a:1005613304674.

Førland E.J. \& Hanssen-Bauer I. 2003. Past and future climate variations in the Norwegian Arctic: overview and novel analyses. Polar Research 22, 113-124, http://dx.doi. org/10.1111/j.1751-8369.2003.tb00102.x.

Fountain A.G., Nylen T.H., Monaghan A., Basagic H.J. \& Bromwich D. 2010. Snow in the McMurdo Dry Valleys, Antarctica. International Journal of Climatology 30, 633-642, http://dx.doi.org/10.1002/joc.1933.

Hanssen-Bauer I. \& Førland E.J. 1998. Long-term trends in precipitation and temperature in the Norwegian Arctic: can they be explained by changes in atmospheric circulation patterns? Climate Research 10, 143-153, http://dx.doi. org/10.3354/cr010143.

Kaesmacher O. \& Schneider C. 2011. An objective circulation pattern classification for the region of Svalbard. Geografiska Annaler Series A 93A, 259-271, http://dx.doi. org/10.1111/j.1468-0459.2011.00431.x.

Knuth S.L., Tripoli G.J., Thom J.E. \& Weidner G.A. 2010. The influence of blowing snow and precipitation on snow depth change across the Ross Ice Shelf and Ross Sea regions of Antarctica. Journal of Applied Meteorology and Climatology 49, 1306-1321, http://dx.doi. org/10.1175/2010jamc2245.1.

Lang C., Fettweis X. \& Erpicum M. 2015. Stable climate and surface mass balance in Svalbard over 1979-2013 despite the Arctic warming. Cryosphere 9, 83-101, http://dx.doi. org/10.5194/tc-9-83-2015.

Lehning M., Naaim F., Naaim M., Brabec B., Doorschot J., Durand Y., Guyomarc'h G., Michaux J.L. \& Zimmerli M. 2002. Snow drift: acoustic sensors for avalanche warning and research. Natural Hazards and Earth System Sciences 2, 121-128, http://dx.doi.org/10.5194/nhess-2-121-2002.

Lenaerts J.T.M., Smeets C., Nishimura K., Eijkelboom M., Boot W., Van Den Broeke M.R. \& Van De Berg W.J. 2014. Drifting snow measurements on the Greenland Ice Sheet and their application for model evaluation. Cryosphere 8 , 801-814, http://dx.doi.org/10.5194/tc-8-801-2014.

Li L. \& Pomeroy J.W. 1997. Probability of occurrence of blowing snow. Journal of Geophysical Research-Atmospheres 102, 21955-21964, http://dx.doi.org/10.1029/97jd01522.
Liston G.E., Sud Y.C. \& Wood E.F. 1994. Evaluating GCM and land-surface hydrology parameterizations by computing river discharges using a runoff routing model-application to the Mississippi Basin. Journal of Applied Meteorology 33, 394-405, http://dx.doi.org/10.1175/1520-0450(1994)033 $<0394$ :eglshp>2.0.c0;2.

Mekonnen G.B., Matula S., Dolezal F. \& Fisak J. 2015. Adjustment to rainfall measurement undercatch with a tipping-bucket rain gauge using ground-level manual gauges. Meteorology and Atmospheric Physics 127, 241-256, http://dx.doi.org/10.1007/s00703-014-0355-z.

Oerlemans J. 2001. Glaciers and climate change. Rotterdam: A. A. Balkema.

Østby T.I., Schuler T.V., Hagen J.O., Hock R., Kohler J. \& Reijmer C.H. 2017. Diagnosing the decline in climatic mass balance of glaciers in Svalbard over 1957-2014. The Cryosphere 11, 191-215, http://dx.doi.org/10.5194/ tc-11-191-2017.

Osuch M. \& Wawrzyniak T. 2017. Inter- and intra-annual changes in air temperature and precipitation in western Spitsbergen. International Journal of Climatology 37, 3082-3097, http://dx.doi.org/10.1002/joc.4901.

Pomeroy J.W., Gray D.M., Shook K.R., Toth B., Essery R.L.H., Pietroniro A. \& Hedstrom N. 1998. An evaluation of snow accumulation and ablation processes for land surface modelling. Hydrological Processes 12, 2339-2367, http://dx.doi. org/10.1002/(SICI) 1099-1085 (199812) 12:15<2339::AIDHYP800>3.0.CO;2-L.

Pramanik A., Van Pelt W., Kohler J. \& Schuler T.V. 2018. Simulating climatic mass balance, seasonal snow development and associated freshwater runoff in the Kongsfjord basin, Svalbard (1980-2016). Journal of Glaciology 64, 943-956, http://dx.doi.org/10.1017/jog.2018.80.

Rogers A.N., Bromwich D.H., Sinclair E.N. \& Cullather R.I. 2001. The atmospheric hydrologic cycle over the Arctic Basin from reanalyses. Part II: interannual variability. Journal of Climate 14, 2414-2429, http://dx.doi.org/10.117 5/1520-0442(2001)014<2414:tahcot>2.0.co;2.

Ryan W.A., Doesken N.J. \& Fassnacht S.R. 2008. Evaluation of ultrasonic snow depth sensors for U.S. snow measurements. Journal of Atmospheric and Oceanic Technology 25, 667-684, http://dx.doi.org/10.1175/2007jtecha947.1.

Schuler T.V., Crochet P., Hock R., Jackson M., Barstad I. \& Jóhannesson T. 2008. Distribution of snow accumulation on the Svartisen ice cap, Norway, assessed by a model of orographic precipitation. Hydrological Processes 22, 3998-4008, http://dx.doi.org/10.1002/hyp.7073.

Serreze M.C., Box J.E., Barry R.G. \& Walsh J.E. 1993. Characteristics of Arctic synoptic activity, 1952-1989. Meteorology and Atmospheric Physics 51, 147-164, http://dx. doi.org/10.1007/bf01030491.

Simmonds I., Keay K. \& Bye J.A.T. 2012. Identification and climatology of Southern Hemisphere mobile fronts in a modern reanalysis. Journal of Climate 25, 1945-1962, http://dx.doi.org/10.1175/jcli-d-11-00100.1.

Smith R.B. \& Barstad I. 2004. A linear theory of orographic precipitation. Journal of the Atmospheric Sciences 61, 1377-1391, http://dx.doi.org/10.1175/1520-0469(2004)0 61<1377:altoop $>2.0$.co; 2 . 
Sorteberg A. \& Walsh J.E. 2008. Seasonal cyclone variability at $70^{\circ} \mathrm{N}$ and its impact on moisture transport into the Arctic. Tellus $A$ 60, 570-586, http://dx.doi. org/10.1111/j.1600-0870.2008.00314.x.

Sorteberg H.K., Engeset R.V. \& Udnaes H.C. 2001. A national network for snow monitoring in Norway: snow pillow verification using observations and models. Physics and Chemistry of the Earth Part C 26, 723-729, http://dx.doi. org/10.1016/s1464-1917(01)95016-0.

Sugiura K., Ohata T. \& Yang D.Q. 2006. Catch characteristics of precipitation gauges in high-latitude regions with high winds. Journal of Hydrometeorology 7, 984-994, http://dx. doi.org/10.1175/jhm542.1.

Tsukernik M., Kindig D.N. \& Serreze M.C. 2007. Characteristics of winter cyclone activity in the northern North Atlantic: insights from observations and regional modeling. Journal of Geophysical Research-Atmospheres 112, D03101, http://dx.doi.org/10.1029/2006jd007184.

Van Pelt W. \& Kohler J. 2015. Modelling the long-term mass balance and firn evolution of glaciers around Kongsfjorden, Svalbard. Journal of Glaciology 61, 731-744, http://dx.doi.org/10.3189/2015JoG14J223.
Van Pelt W.J.J., Kohler J., Liston G.E., Hagen J.O., Luks B., Reijmer C.H. \& Pohjola V.A. 2016. Multidecadal climate and seasonal snow conditions in Svalbard. Journal of Geophysical Research-Earth Surface 121, 2100-2117, http:// dx.doi.org/10.1002/2016jf003999.

Walsh J.E., Zhou X., Portis D. \& Serreze M.C. 1994. Atmospheric contribution to hydrologic variations in the Arctic. Atmosphere-Ocean 32, 733-755, http://dx.doi.org/1 0.1080/07055900.1994.9649520.

Wolff M.A., Isaksen K., Petersen-Overleir A., Odemark K., Reitan T. \& Braekkan R. 2015. Derivation of a new continuous adjustment function for correcting wind-induced loss of solid precipitation: results of a Norwegian field study. Hydrology and Earth System Sciences 19, 951-967, http://dx. doi.org/10.5194/hess-19-951-2015.

Zemp M., Thibert E., Huss M., Stumm D., Denby C.R., Nuth C., Nussbaumer S.U., Moholdt G., Mercer A., Mayer C., Joerg P.C., Jansson P., Hynek B., Fischer A., Escher-Vetter H., Elvehoy H. \& Andreassen L.M. 2013. Reanalysing glacier mass balance measurement series. Cryosphere 7, 1227-1245, http://dx.doi.org/10.5194/ tc-7-1227-2013. 